DOI: $10.5277 /$ epe 160311

\title{
DYNAMIC OLFACTOMETRY AND MODELING AS METHODS FOR THE ASSESSMENT OF ODOUR IMPACT OF PUBLIC UTILITY OBJECTS
}

\begin{abstract}
The methods used to the identification of odour concentrations from public utility objects, under Polish legal regulations have been presented with exemplary results of measurements by the dynamic olfactometry and model calculations. The results of the study indicate the usefulness of the dynamic olfactometry in determining odour concentrations (from point and area emission sources located in public utility objects) suitable in odour emissions calculations. Based on results of such calculations, it is possible to determine odour concentrations in the receptor points and to evaluate olfactory impact range of considered objects, taking into account all types of odour sources affecting the quality of air in the area under study. Selected methods - as an alternative to field research: measurements in the grid and in the plume - can be less time and cost consuming but also require careful planning the number of samples and proper selection of representative sampling areas, especially in the case of the area sources.
\end{abstract}

\section{INTRODUCTION}

One of the distinctive features of chemical substances emitted in waste treatment processes is their smell which is a matter of individual perception, depending on individual features. Smell is defined as an olfactory sensation, recorded by brain due to the olfactory receptors stimulation with chemical stimulus [1]. The emission of odours may significantly affect the quality of life of people, affecting their health and comfort. With long term exposure, odours may cause discomfort, anxiety, depression, insomnia, loss of appetite, headaches, respiratory system disorders, nausea and vomiting [2]. What is more, the emission of odours may significantly reduce the quality of environment, thus

${ }^{1}$ Unit of Ecologistics and Environmental Risk Management, Faculty of Environmental Engineering, Wrocław University of Science and Technology, pl. Grunwaldzki 9, 50- 377 Wrocław, Poland, corresponding author I. Sówka, e-mail: izabela.sowka@pwr.edu.pl 
its landscape and environmental benefits and economical potential (through loss or distortion of a real estate use or running a business) [3]. Both external factors (emission parameters, physical conditions determining odour dispersion in the air and their immision), and individual ones (personal features, the state of environment, life situation) may affect odour nuisance.

The aim of the study was to determine the suitability of the use of dynamic olfactometry and mathematical modeling in the evaluation of the olfactory assessment of public utility objects in Poland. The results of odour concentrations in samples taken from the sources located on the studied utility areas and the calculations obtained with Polish reference model are presented. The quantitative characterization of municipal objects in Poland, in conjunction with an indication of the possibility of odour emissions and a review of selected methods used in odour assessment of air quality in Europe and Poland have been described.

Many air pollutants emitted both from municipal and industrial objects come in low concentrations but often have low odour detection thresholds, what may cause odour nuisance [3]. An important potential source of odour emission are public utility objects. These objects have many different emission sources, with a predominance of diffuse sources. Main types of public utility objects are: sewage systems, wastewater treatment plants, landfills, waste sorting and processing plants.

According to Polish Central Statistical Office annual data for 2013, in Poland there are 3191 municipal wastewater treatment plants, including 55 mechanical treatment plants and 2316 biological ones, as well as 820 plants with increased removal of nutrients. Inventory of public utility objects showed there are also: 206 municipal waste sorting plants, 87 green and biodegradable waste composting plants, 11 mechanical and biological mixed municipal waste processing plants and 1423 landfills [4]. Both sewage and waste treatment objects are aimed to reduce negative environmental impact of human activities. The common feature of these objects is the similarity of chemical composition of the emitted odours and their hedonic quality. Depending on the type of the source, they differ in size and the intensity of odour emission, what can affect the scale of odour nuisance.

Odour emission from public utility objects depends both on the type of the object as well as on used technological solutions. In wastewater management, the emission of odorous gases occurs at various stages of the technological system, beginning with sewage transport, through mechanical and biological sewage treatment, to sludge treatment [4]. Aeration of sewage inhibits its rotting processes and formation of anaerobic conditions but at the same time it intensifies emission of odorous gases.

Pollutants typically occurring in gases emitted in wastewater and sewage sludge treatment processes are: ammonia, hydrogen sulfide, alkylthiols, aliphatic amines, aldehydes, ketones, fatty acids, alkyl sulfides and disulfides [4]. Odour emission during sewage transport is affected both by sewage parameters such as temperature or $\mathrm{pH}$, as well as transport conditions, e.g. proper aeration. Transport conditions and the state of 
wastewater reaching the sewage treatment plant have an impact on odour emissions on following stages of sewage treatment. Also conditions under which technological processes are carried out may affect odour emissions. A particular nuisance in terms of odour emissions may be related to processes associated with sludge management such as thickening and drying of sewage sludge. An important element affecting reduction of odour nuisance, associated with sewage treatment is organisation and encapsulation of odour emission sources and deodorization of emitted gases.

In the case of municipal waste treatment objects, odorants may be primary (contained in delivered waste) and secondary (substances produced during biological and chemical processes) [5]. The processes during which odours are emitted are: sorting and storage of waste, mechanical and biological waste processing, including composting. Biodegradation processes take place in several stages and the largest emission occurs in anaerobic conditions.

Typical pollutants emitted in waste treatment objects are methyl and ethyl amines, hydrogen sulfide, methane, ethane and butanethiol, carboxylic acids (formic, acetic and propionic ones) and alcohols (methanol, ethanol, $n$-butanol). Hydrogen sulfide and alkyl thiols are considered most responsible for odour nuisance, according to odour detection thresholds. In order to reduce odour nuisance deriving from municipal waste treatment objects, it is particularly important to conduct technological processes properly and to choose an appropriate localization of the object.

\section{SELECTED METHODS IN THE ODOUR AIR QUALITY ASSESSMENT}

There are many methods to assess air quality in terms of presence of odours and they can be divided into three basic groups: analytical chemistry methods used to analyze chemical composition of odorants mixtures and to measure concentrations of particular chemical compounds (with the use of chromatography), sensoric methods using human sense of smell, with which odour concentration, intensity, hedonic quality and frequency of the odour is measured (dynamic olfactometry, static dilution olfactometry, field measurements, survey research and odour dispersion modelling); instrumental and sensory methods using sensor units acting similarly to human sense of smell (electronic nose) [6-9]. Analytical methods allow to determine composition of odorant mixtures and their concentration but very often cannot determine main cause of odour. It is due to the specific nature of odour impact and reactions occurring between individual odorants, as well as to the rate of change of odour intensity with concentration changes and low odour detection thresholds. Methods most commonly used in assessment of odour air quality include dynamic olfactometry, field measurements and model calculations [3]. 


\subsection{DYNAMIC OLFACTOMETRY}

Odour concentration measurement techniques include static dilution method and dynamic olfactometry [10]. Both of them are sensory methods in which air samples containing odorants in various concentrations are assessed by a team of evaluators. Depending on the type of question, the evaluator is asked, following methods are distinguished [1]: "yes - no" method, in which answers to the question: "Can you smell gas sample?" are collected; differential method: even (the evaluators answer to the question: "Is the smell of a gas sample stronger than the other smell, presented at the same time?"), triangular (answers to the question: "Which of the three of the simultaneously presented samples, smell different from the other two?" are collected); "duo - trio" method (answers to the question: "Which of the two of the unmarked samples is identical to the third, designated as a model?" are collected); indirect methods (extrapolative) - the evaluators' opinions on samples with higher concentrations than the odour detection threshold are collected, the evaluators also compare the smell of a diluted gas with the odour intensity scale.

Procedures for collecting gas samples from point sources, passive and active surface sources and determination of odour concentration by dynamic olfactometry are described in the PN-EN 13725 standard. The main objective of the standard is to ensure the consistency of the odour emission assessments in the European Union. Dynamic olfactometry allows one to determine odour concentration of individual substances and mixtures of odorants.

Odour concentration is expressed in European odour unit per cubic meter $\left(\mathrm{ou}_{\mathrm{E}} / \mathrm{m}^{3}\right)$. $1 \mathrm{ou}_{\mathrm{E}} / \mathrm{m}^{3}$ is equivalent to the amount of odorant which is still sensed by half of the test group, after evaporation in the volume of $1 \mathrm{~m}^{3}$ of inert gas, under standard conditions. The device used to determine odour concentration is dynamic olfactometer. Dilutions of the samples are obtained by mixing two gas streams: sample and clean, odourless air.

The olfactometer dilution ranges from $2^{2}$ to $2^{16}$. The device is connected to a computer with special software, that allows one to control the operation of the dilution system and the automatic execution of statistical calculations and presentation of results. The measuring unit consists of at least four evaluators (depending on the olfactometer construction, e.g. 4- or 8-position olfactometer) and the operator inspecting the measurement process and controlling evaluated sample dilutions selection. The measurement is performed with the "yes - no" method. During selected dilution series, the evaluators alternately receive air and an odorant sample at given concentration.

To assess the reliability of answers, so called blind tests are performed - replacement of odorant sample with clean air. To perform the measurement, members of the evaluation team must have a defined and possible constant sensitivity to the adopted standard sample, e.g. $n$-butanol in nitrogen. The mean of individual odour detection thresholds should range from $0.02 \mu \mathrm{mol} / \mathrm{mol}$ to $0.080 \mu \mathrm{mol} / \mathrm{mol}$ (the range between 0.5 and 2 times the reference value adopted for $n$-butanol). 
Based on determined odour concentration in collected samples, it is possible to calculate the odour emissions, and obtained values can be used to the olfactory impact assessment of objects that can cause odour nuisance.

\subsection{FIELD RESEARCH}

Odour nuisance measurements can be carried out in situ in various ways, through field research. There are two basic types of field research: measurement in the grid and in the plume (VDI 3940). These measurements are performed to estimate the range of odour impact of selected objects by determining the frequency (odour hours) and intensity of odour. Measurements are performed at a certain time (according to VDI 3883, recommended time is 6 months) in following, regular sessions, representative for all seasons. Just as in the method of dynamic olfactometry, the members of the of field inspectors team must be properly trained and have a certain perception of smell. Field research may be supplemented by surveys or odour observation diaries, distributed among the people living in the area around the test object.

\subsection{MODEL CALCULATIONS}

By using some mathematical tools, it is possible to determine the odour immision and the range of odour impact of selected object, on the basis of a particular value of odour concentration and emission [11-15] . Mathematical models of odour dispersion in the air based on models used to determine dispersion of airborne substances.

Main parameters considered in modelling are: odour emission, meteorological conditions and transport of pollutants and their transformations in the atmosphere. There is a lack of legal regulations concerning odour concentrations limits and frequency of exceedances of limit values in Poland. In the draft of act of 27 February 2009 on prevention of odour nuisance, an established limit of permitted frequency of exceedances was set to $3 \%$ with the reference value of $\mathrm{ou}_{\mathrm{E}} / \mathrm{m}^{3}$. However, according to various reports, odour concentrations on levels of $2-5 \mathrm{ou}_{\mathrm{E}} / \mathrm{m}^{3}$, does not necessarily cause odour nuisance (the smell is too "weak") [3]. Under Polish conditions, if is a need, olfactory impact assessment of objects is calculated for two scenario: for the odour concentrations 1 and $5 \mathrm{ou}_{\mathrm{E}} / \mathrm{m}^{3}$ and frequency of exceedances $3 \%$ and $2 \%$, respectively.

\section{EXEMPLARY RESULTS AND DISCUSSION}

In Table 1, examples of odour concentrations measured in gasses emitted from selected point and area sources located in the area of Polish public utility objects are provided. 
Table 1

Examples of odour concentrations measured in selected public utility objects

\begin{tabular}{|c|c|c|}
\hline Object/type(s) of installation & Source of odour & $\begin{array}{c}\text { Averaged odour } \\
\text { concentrations } \\
{\left[\mathrm{ou} / \mathrm{m}^{3}\right]}\end{array}$ \\
\hline \multirow{12}{*}{$\begin{array}{l}\text { WWTP } 1 \\
\text { Wastewater treatment plant }\end{array}$} & biofilter - lattice hall & 8138 \\
\hline & biofilter - grit chamber hall & 2017 \\
\hline & lattice hall & 1277 \\
\hline & biofilter-digested sludge tanks hall & 2372 \\
\hline & biofilter - sludge thermal drying station & 19916 \\
\hline & \begin{tabular}{|l|} 
thickener \\
\end{tabular} & 37991 \\
\hline & \begin{tabular}{|l|} 
secondary clarifier \\
\end{tabular} & 119 \\
\hline & primary settling tank & 11130 \\
\hline & dephosphatation chamber & 8918 \\
\hline & denitrification chamber & 3873 \\
\hline & predenitrification chamber & 128 \\
\hline & nitrification chamber & 59 \\
\hline \multirow{3}{*}{$\begin{array}{l}\text { IPSCGBW } 1 \\
\text { The installation of processing of separately } \\
\text { collected green and bio-waste - composting }\end{array}$} & product reception and storage area & 506 \\
\hline & composting area & 25 \\
\hline & waste storage emergency zone & 969 \\
\hline \multirow{4}{*}{$\begin{array}{l}\text { IPSCGBW } 2 \\
\text { The installation of processing of separately } \\
\text { collected green and bio-waste - composting } \\
\text { Installation of mechanical-biological treatment } \\
\text { of mixed municipal waste - MBT }\end{array}$} & biological stabilization & 1178 \\
\hline & landfill & 105 \\
\hline & leachate tank & 116 \\
\hline & & \\
\hline $\begin{array}{l}\text { Installation for the disposal of waste generated } \\
\text { in the process mechanical-biological treatment } \\
\text { of mixed municipal waste and residues } \\
\text { from municipal waste sorting - landfill }\end{array}$ & waste sorting building & 1010 \\
\hline \multirow{3}{*}{$\begin{array}{l}\text { IPSCGBW } 3 \\
\text { The installation of processing of separately } \\
\text { collected green and bio-waste - composting }\end{array}$} & biofilter - composting hall & 404 \\
\hline & mixed waste storage area & 3178 \\
\hline & $\begin{array}{l}\text { mechanical processing } \\
\text { and storage of waste hall }\end{array}$ & 115 \\
\hline $\begin{array}{l}\text { The installation of mechanical-biological } \\
\text { treatment of mixed municipal waste - MBT }\end{array}$ & leachate from the composting & 6596 \\
\hline $\begin{array}{l}\text { IPSCGBW } 4 \\
\text { The installation of processing of separately } \\
\text { collected green and bio-waste - composting } \\
\text { Installation of mechanical-biological } \\
\text { treatment of mixed municipal waste - MBT }\end{array}$ & biofilter - composting hall & 559 \\
\hline
\end{tabular}

In the objects listed in the table, the main elements of technological processes as a source of odour emissions were selected, odour samples were taken and the odour 
concentrations were determined with the use of dynamic olfactometry method, in a stationary Olfactometric Laboratory at the Wrocław University of Science and Technology, in accordance with the Polish and European standards. For sampling in a tested wastewater treatment plant (WWTP1) and the installations of processing of separately collected green and bio-waste (IPSCGBW1-IPSCGBW4), depending on the type of source, certain types of samplers were used and in the case of area sources, representative areas in accordance with the PN-EN 13725 and VDI 3880 were designated.

Based on the determined odour concentrations in collected samples, it was possible to calculate the odour emissions. For a selected object: IPSCGBW1 - the installation of processing of separately collected green and bio-waste - standard variant of work was established, i.e. the technological processes carried out on the composting plant run properly and during the whole year of operation there was no situation of waste disposal in the waste storage emergency zone. Odours were: 1) emitted from two surface sources: product reception and storage area (E1) and composting area (E2) - calculated odour emission values are listed in Table 2) air was directed into two separate opened biofilters with the surface of $35 \mathrm{~m}^{2}$, height of $3 \mathrm{~m}$ and deodorization efficiency of $90 \%$ that resulted in the odour emission values equal to 2201 and $805 \mathrm{ou}_{\mathrm{E}} / \mathrm{s}$, respectively.

Applying the Polish reference model based on Pasquill formula, the frequency of exceedances of the odour in the study area were calculated for the odor concentrations 1 and $5 \mathrm{ou}_{\mathrm{E}} / \mathrm{m}^{3}$ and frequency of exceedances $3 \%$ and $2 \%$, respectively (Figs. 1 and 2). Calculations were carried out in a grid of receptors (the size of $900 \mathrm{~m} \times 900 \mathrm{~m}$ and the step of $25 \mathrm{~m}$ ), with: the assumed value of the aerodynamic roughness coefficient of $2 \mathrm{~m}$, emitter working time of $8760 \mathrm{~h}$, wind rose for the meteorological station in Wrocław and the closest residential buildings on a height of $3 \mathrm{~m}, 4 \mathrm{~m}$ and $5 \mathrm{~m}$ (two residential buildings located approximately 220 meters away from the analyzed object).

Table 2

Odour emission values calculated for IPSCGBW 1:

the installation of processing of separately collected green and bio-waste composting

\begin{tabular}{|l|c|c|c|c|}
\hline Odour source & $\begin{array}{c}\text { Odour } \\
\text { concentration } \\
{\left[\mathrm{ouE}_{\mathrm{E}} \mathrm{m}^{3}\right]}\end{array}$ & $\begin{array}{c}\text { Specific odour } \\
\text { emission } \\
\text { rate }(\mathrm{SOER}) \\
{\left[\mathrm{ou}_{\mathrm{E}} /\left(\mathrm{m}^{2} \cdot \mathrm{s}^{1}\right)\right]}\end{array}$ & $\begin{array}{c}\text { Area } \\
\text { of the odour } \\
\text { source } \\
{\left[\mathrm{m}^{2}\right]}\end{array}$ & $\begin{array}{c}\text { Odour emission } \\
{\left[\mathrm{ou}_{\mathrm{E}} / \mathrm{s}^{1}\right]}\end{array}$ \\
\hline $\begin{array}{l}\text { Product reception } \\
\text { and storage area } \\
\text { (E1) }\end{array}$ & 506 & 88.04 & 250 & 22011 \\
\hline $\begin{array}{l}\text { Composting area } \\
\text { (E2) }\end{array}$ & 25 & 4.35 & 1850 & 8048 \\
\hline
\end{tabular}

The results of the calculations indicate that the permissible exceedances frequency value $(3 \%)$ was exceeded only for $1 \mathrm{ou}_{\mathrm{E}} / \mathrm{m}^{3}$ (Fig. 1) but it should be noted that exceeded 
values were up to $70 \mathrm{~m}$ from the boundaries of the tested plant and did not include the areas inhabited by humans. The permissible frequency of exceedances of $5 \mathrm{ou}_{\mathrm{E}} / \mathrm{m}^{3}$ equal to $2 \%$ was not exceeded at any point in the computational grid (Fig. 2).

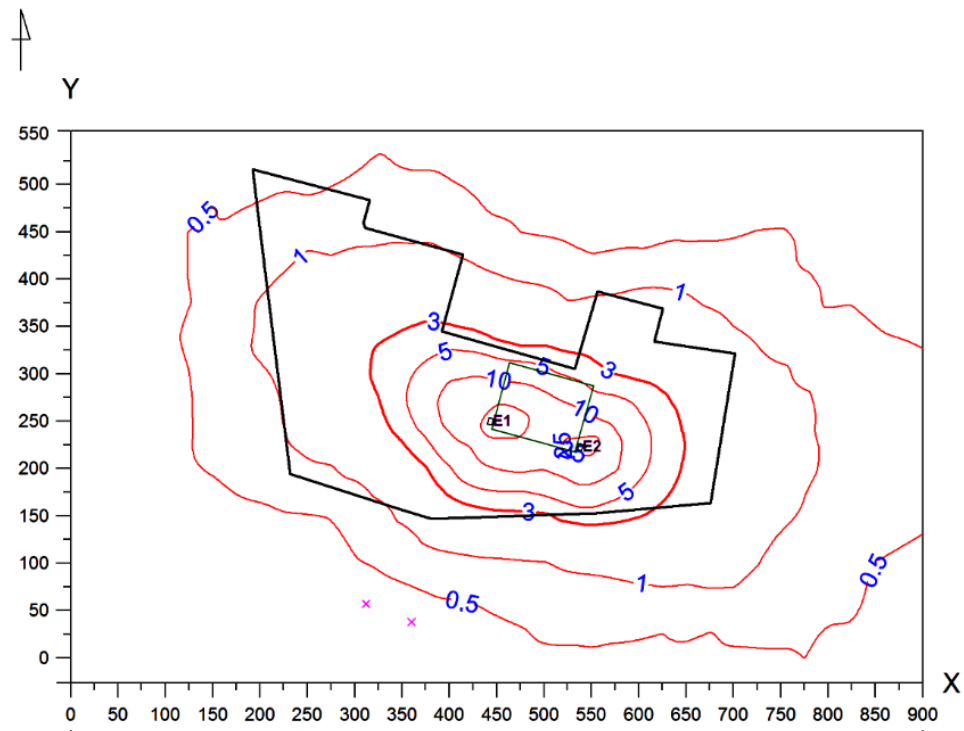

Fig. 1. The distribution of exceedances frequency of odour concentrations, $1 \mathrm{ou}_{\mathrm{E}} / \mathrm{m}^{3}$ :

thick line - area of the composting plant, E1, E2 - emission sources, $\times$ - residential buildings location

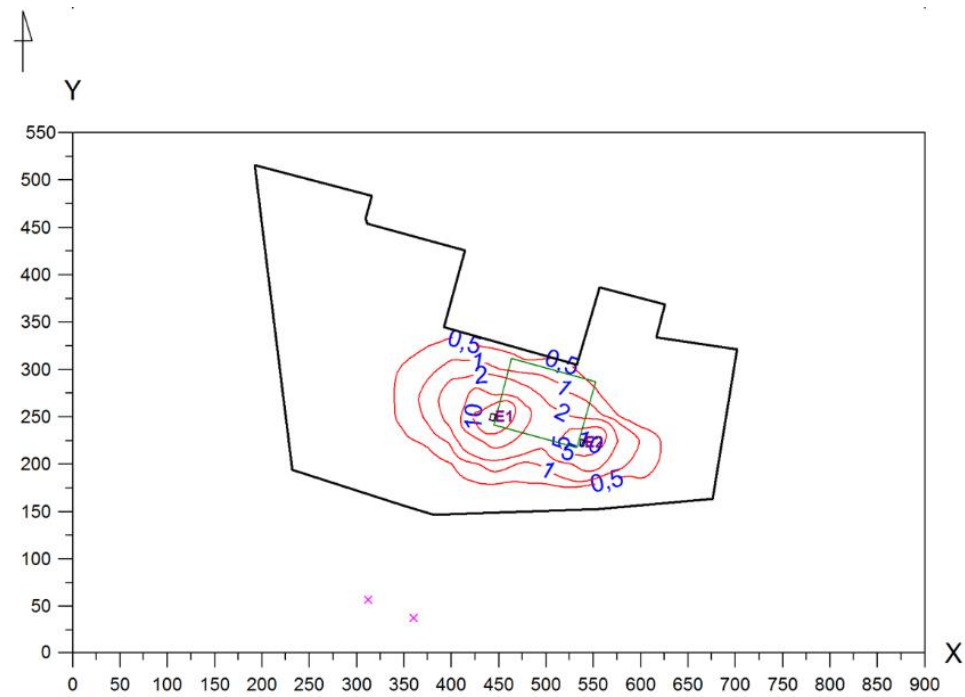

Fig. 2. The distribution of exceedances frequency of odour concentrations, $5 \mathrm{ouE} / \mathrm{m}^{3}$ : thick line - area of the composting plant; E1, E2 - emission sources, $\times-$ residential buildings location 
Calculations performed on the height of two buildings showed no negative olfactory effects. The limit of the frequency of exceedances of the both odour concentrations $1 \mathrm{ou}_{\mathrm{E}} / \mathrm{m}^{3}$ and $5 \mathrm{ou}_{\mathrm{E}} / \mathrm{m}^{3}$ was not exceeded, therefore no negative impact on the residential buildings adjacent to the considered plant can be concluded.

Olfactometry analyses have many advantages as well as some disadvantages. Olfactometry is the best method for determination of odour concentration because of complex nature of odours, which are often mixtures of various compounds in low concentrations, which have great effect on the intensity of odour [16]. Odour detection thresholds are often so low that they are lower than detection limits of some analytical methods. At the same time it is proven that components of odour mixture affects its smell - increasing or reducing odour concentration of the mixture. Due to that fact, determining odour concentration of a gas sample using analytical methods can result in high level of inaccuracy when not taking into account synergy and masking effects that occur in the sample, as well as odour threshold concentration values, which have high level of inaccuracy, differing by several orders of magnitude depending on literature source [17].

The main limitation of dynamic olfactometry is inability to perform continuous measurements making it unable to conduct continuous monitoring of odour nuisance in the area. Secondly dynamic olfactometry is time-consuming and relatively expensive so it limits high frequency of odour concentrations determination in a specific area comparing to analytical methods [18].

\section{SUMMARY}

To assess the olfactory impact of municipal facilities in Poland, dynamic olfactometry and modeling studies can be applied. Field studies can be also used but because of the long time needed to carry out the field measurements and the potential costs of research, it seems economically reasonable under Polish conditions to use emissions measurements and analyzes of odour dispersion modelling results for the olfactory impact assessment of the public utility objects.

Considered methods may be sufficient in determining the odour impact range, especially if there is a need for fast and reliable assessment of the impact of public utility objects. Especially in areas where there are no public complaints and there is no need for time and cost consuming field research.

ACKNOWLEDGEMENTS

This work was supported by a statutory research No. S50-563. 


\section{REFERENCES}

[1] KoŚmider J., WyszyŃSki B., Mazur-ChrZANowska B., Odours, PWN, Warsaw 2002 (in Polish).

[2] Nicell J., Assessment and regulation of odour impacts, Atmos. Environ., 2009, 43, 196.

[3] BelgioRno V., NAdDEO V., ZARRA T., Odour impact assessment handbook, Wiley, 2013.

[4] Szynkowska M., Zwoździak J., Present Odours Issues, WNT, Warsaw 2010 (in Polish).

[5] Frederickson J., Boardman C.P., Gladding T.L., Simpson A.E., Howell G., Sgouridis F., Evidence: Biofilter performance and operation as related to commercial composting, Environ. Agency, Bristol 2013.

[6] HaAs T., Schulze-Lammers P., Diekmann B., Horner G., Boeker P., A method for online measurement of odour with a chemosensor system, Sensor. Actuat. B: Chem., 2008, 132.

[7] Micone P.G., GuY C., Odour quantification by a sensor array: an application to landfill gas odours from two different municipal waste treatment works, Sensor. Actuat. B: Chem., 2007, 120.

[8] Sironi S., CAPElli L., CEntola P., Rosso R.D., Continuous monitoring of odours from a composting plant using electronic noses, Waste Manage., 2007, 27.

[9] Bourgeois W., STUETZ R.M., Use of a chemical sensor array for detecting pollutants in domestic wastewater, Water Res., 2006, 36.

[10] Sironi S., CAPelli L., CÉntola P., Rosso R.D., PieruCCi S., Odour impact assessment by means of dynamic olfactometry, dispersion modelling and social participation, Atmos. Environ., 2010, 44 (3) 354.

[11] HENSHAW P., NicEll J., SiKDAR A., Odour impact parameters for an industrial facility, Atmos. Environ., 2006, 40.

[12] Mahin T.D., Comparison of different approaches used to regulate odours around the world, Water Sci. Technol., 2011, 44 (9), 87.

[13] Mussio P., GNyP A.W., Henshaw P.F., A fluctuating plume dispersion model for the prediction of odour-impact frequencies from continuous stationary sources, Atmos. Environ., 2001, 35 (16), 2955.

[14] Schauberger G., Piringer M., Petz E., Separation distance to avoid odour nuisance due to livestock calculated by the Austrian odour dispersion model (AODM), Agr. Ecosyst. Environ., 2001, 87 (1), 13.

[15] SYKES R.I., GABRUK R.S., A 2nd-order closure model for the effect of averaging time on turbulent plume dispersion, J. Appl. Meteorol., 1997, 36, 1038.

[16] EUI-ChAN J., HyUn-KeUn S., JAE-HwAN S., Emission characteristics and factors of selected odorous compounds at a wastewater treatment plant, Sensors, 2009, 9, 311.

[17] CAPelli L., Sironi S., Del Rosso R., CÉntola P., Il Grande M., A comparative and critical evaluation of odour assessment methods on a landfill site, Atmos. Environ., 2008, 42, 7050.

[18] Brattoli M., De Gennaro G., De Pinto V., Demarinis Loiotile A., Lovascio S., PenZa M., Odour detection methods. Olfactometry and chemical sensors, Sensors, 2011, 11, 5290. 